Review

\title{
Antihypertensive Properties of Plant-Based Prebiotics
}

\author{
Siok-Koon Yeo, Lay-Gaik Ooi, Ting-Jin Lim and Min-Tze Liong *
}

School of Industrial Technology, Universiti Sains Malaysia, 11800 Penang, Malaysia; E-Mails: siokkoon85@yahoo.com (S.Y.); ooilaygaik@yahoo.com (L.O.); ericlimtingjin@hotmail.com (T.L.)

* Author to whom correspondence should be addressed; E-Mail: mintze.liong@usm.my; Tel. +604-653-2114; Fax: +604-657-3678

Received: 25 June 2009; in revised form: 14 July 2009 / Accepted: 28 July 2009 /

Published: 10 August 2009

\begin{abstract}
Hypertension is one of the major risk factors for cardiovascular disease. Although various drugs for its treatment have been synthesized, the occurring side effects have generated the need for natural interventions for the treatment and prevention of hypertension. Dietary intervention such as the administration of prebiotics has been seen as a highly acceptable approach. Prebiotics are indigestible food ingredients that bypass digestion and reach the lower gut as substrates for indigenous microflora. Most of the prebiotics used as food adjuncts, such as inulin, fructooligosaccharides, dietary fiber and gums, are derived from plants. Experimental evidence from recent studies has suggested that prebiotics are capable of reducing and preventing hypertension. This paper will discuss some of the mechanisms involved, the evidence generated from both in-vitro experiments and in-vivo trials and some controversial findings that are raised.
\end{abstract}

Keywords: prebiotics; mechanism; evidence; controversies; inulin; fos; fiber; gum

\section{Introduction}

Hypertension is defined as an elevation in blood pressure, where a blood pressure exceeding 140/90 $\mathrm{mm} \mathrm{Hg}$ is considered as elevated, and a lower threshold of 130/80 mm Hg was applied for individuals with diabetes or chronic kidney disease [1]. Hypertension has been identified as one of the risk factors for the emergence of cardiovascular diseases. Past hypertension intervention trials have 
revealed that the risk treatment of hypertension could reduce the risks of stroke by $42 \%$ and a $14 \%$ reduction in coronary heart disease [2]. In order to treat hypertension, synthetic drugs have been developed by the pharmaceutical industry. However, such drugs have been reported to produce side effects including insomnia, angioedema, cough and fetal abnormalities [3]. Considering the side effects of synthetic drugs, dietary treatment has gained much attention lately as the alternative antihypertensive approach. Dietary components including prebiotics are seen as better alternatives than drug therapy to treat hypertension considering that prebiotics has a long history of safe use and has been a natural component present in our foods.

Prebiotics are non-digestible food ingredients that can escape digestion under the harsh conditions of the upper gastrointestinal tract and reach the lower gut as substrates for the fermentation by selective indigenous gut microflora. Most of the prebiotics studied are plant derivatives such as fructooligosaccharides (FOS), inulin and fibers. FOS contains 2 to 10 fructose units linked by glycosidic bonds, while inulin is a fructose polymer with $\beta$-(2-1) glycosidic linkages with chains of 3 to 60 units. Both FOS and inulin are found abundantly in chicory and artichokes. The major component of chicory root is inulin. Inulin belongs to the fructan family, and occurs naturally as important storage carbohydrates. Other than chicory, fructans are also found present in artichokes, salsify, asparagus and onions [4]. Plant fibers are also found to exert prebiotic properties, health enhancing effects and strongly influence the metabolism of carbohydrates and lipids, which are directly associated with the increased risks of hypertension. Prebiotics from various plant sources have very different chemical structures, physicochemical properties, and physical states. The extraction of prebiotics, especially of plant fiber origin often relies on water solubility or extractability, where plant fibers can be divided into soluble fibers and insoluble fibers [5]. Both soluble and insoluble fibers have been found to exert hypocholesterolemic and hypoglycemic effects that could subsequently lead to an antihypertensive effect. This paper will discuss some of the antihypertensive mechanisms that have been documents.

This paper will also discuss some of the experimental evidence on the antihypertensive properties of plant derived prebiotics, with emphasis on their hypocholesterolemic and hypoglycemia effects. However, controversies have arisen where some studies showed promising results while others exhibited insignificant findings. Thus, this paper will also highlight some of these controversies.

\section{Antihypertensive Mechanisms of Prebiotics}

Various mechanisms have been postulated to explain the ability of prebiotics to reduce the risk of hypertension. One of the possible mechanisms is via the lowering of blood lipid and cholesterol. Previous studies have demonstrated that intensive reduction of cholesterol may be beneficial in the treatment of patients with isolated systolic hypertension [6]. The lipid and cholesterol lowering effects of prebiotics could be attributed to the production of short chain fatty acids (SCFA). It is commonly known that prebiotics resist digestion in the small intestine and reach the colon, where they are fermented by selective colonic microflora to produce SCFA such as acetate, propionate and lactate. The SCFA produced in the large bowel are absorbed in the portal vein, and a major part is metabolized by the liver and subsequently affects various metabolic processes [7]. Indigenous lactic acid bacteria and bifidobacteria often have the ability to ferment these indigestible prebiotics and produce lactate 
and acetates as the main metabolites, with smaller amounts of propionate and butyrate. It has been reported that propionate could hinder fatty acid and cholesterol synthesis, while lactate produced in the colon plays a significant role in lowering the synthesis of triaclyglycerol fatty acids.

Soluble prebiotics such as pectin, konjac mannan and modified starches are soluble in solutions leading to a thickening and viscous effect. Such physicochemical properties have been found to affect physiological responses such as the lowering of blood cholesterol, and increasing satiety by delaying gastric emptying and a reduced speed of gastric transit in the upper gastrointestinal tract. Levrat-Verny et al. [7] evaluated the hypocholesterolemic effects of soluble prebiotics such as guar gum and xanthan gum by using 56 male Wistar rats as a model. The authors found that the administration of 1\% w/w of the individual prebiotics for three weeks resulted in increased bile acid flux in feces compared to the control, and a subsequent decrease in plasma and liver cholesterol contents. It was postulated that the soluble prebiotics inhibited intestinal cholesterol and bile absorption by increasing the viscosity of the digesta and the thickness of the unstirred layer in the small intestines. Other than soluble prebiotics, insoluble prebiotics have also been found to exert a hypocholesterolemic effect. They are not soluble, thus could shorten the time of gastric transit and increase the bulk of feces. It has been reported that these insoluble prebiotics could absorb fat and phospholipids in the lower intestines, leading to increased excretion in feces. Cholesterol levels have been reported to be reduced via the binding effect of prebiotics. Gallaher et al. [8] proposed that fiber could bind with bile acids and reduce solubilisation of cholesterol leading to a cholesterol lowering effect. The reduction of total cholesterol regulates the receptors of low density lipoprotein (LDL) and thus increases the clearance of LDL cholesterol [9]. This overall cholesterol lowering effect could reduce the stiffness of large arteries and thus could potentially reduce blood pressure [6].

In another study, Lairon et al. [10] suggested that the reduction of obesity upon consumption of prebiotics such as fiber could prevent the elevation of blood pressure. Generally, overweighed and obese individuals are at a higher risk of hypertension than those with a healthy body mass index (BMI) [11]. Obesity has also been commonly associated with the overactivity of the sympathetic nervous system where long-term sympatho-activation could raise arterial pressure by causing peripheral vasoconstriction and by increasing renal tubular sodium reabsorption [11]. Therefore, decreasing obesity upon consumption of prebiotics could help to prevent or reduce the risk of hypertension. Past studies involving animals model mainly rats has shown promising evidence that ingestion of inulin-type fructans could regulate body weight via the promotion of endogenous glucagon-like peptide-1 (GLP-1) in the gut [12]. GLP-1 is a key hormone released from enteroendocrine-L cells in response to nutrient ingestion and is the key modulator of food intake by promoting satiety [13]. This consequently reduces the intake of food which leads to a decreased in body weight and BMI. Most of the studies involving the promotion of satiety by fructans via increased production of GLP-1 were performed in animal models and little information is available on human subjects. However, this remains a possible mechanism of fructans in promoting satiety. Piche et al. [14] had previously demonstrated that ingestion of $6.6 \mathrm{~g}$ of oligofructose three times a day for seven days increased the release GLP-1 in nine subjects. Although the GLP-1 level was not directly associated with satiety in this study, the promotion of GLP-1 in human was a plausible finding of the effects of fructans in human. In addition, it is interesting to note that ingestion of $16 \mathrm{~g} /$ day of oligofructose for two weeks 
decreased the total energy intake by $5 \%$ and increased satiety following breakfast and dinner in human subjects [15].

Another possible mechanism by which prebiotics could regulate blood pressure includes the attenuation of insulin resistance [16]. Insulin resistance is a metabolic disorder and has been associated with impaired endothelium-dependent vasodilatation which could contribute to increased blood pressure [17]. Therefore, the alteration of insulin sensitivity could potentially protect against the development of this cardiovascular disease. Insoluble prebiotics have been found able to address this issue. Insoluble prebiotics are often extracted from native plant fibers such as cellulose, hemicelluloses, lignin and wheat bran. They have been found to improve postprandial glucose response and decreased secretion of insulin via a lowered glycemic index. The lower circulation of insulin up-regulates the insulin receptors and secondary signalling molecules resulting in increased tissue insulin sensitivity [18]. In addition, other insoluble prebiotics such as high cereal fiber has also been associated with the reduced risk of diabetes, mainly attributed to their metabolism in the colon by indigenous microflora producing SCFA and their effects on hepatic insulin sensitivity [19]. SCFA has been suggested to improve hepatic insulin sensitivity [20]. Cereal fiber also has a low glycemic index and has been studied for their roles in managing diabetes via lowering early postprandial hyperglycemia and decreasing risks of post-absorptive hypoglycemia [21].

Additionally, prebiotics have also been reported to reduce the risk of hypertension by improving the absorption of mineral such as calcium in the gastrointestinal tract [22]. Past studies have shown promising evidence on the correlation of dietary calcium and hypertension. Allender et al. [23] conducted a meta analysis of randomized clinical trials on the correlation of dietary calcium and blood pressure and had found that median intake of calcium by $1 \mathrm{~g}$ /day could significantly decrease the systolic blood pressure by $1 \mathrm{~mm} \mathrm{Hg}$ to $2 \mathrm{~mm} \mathrm{Hg}$. Diets high in calcium have been found to reduce peripheral vascular resistance and blood pressure leading to a reduced risk of hypertension [24]. However, the beneficial effect of dietary calcium is dependent on its bioavailability and absorption in the intestinal lumen, and the absorption efficiency of calcium in human is low where only $25-30 \%$ of the calcium intake is being absorbed by the body [25]. The consumption of prebiotics such as inulin has been reported to enhance the absorption of calcium in human [26]. Prebiotics have been reported to increase the absorption of calcium via binding or sequestering calcium in the upper gastrointestinal tract. Bound or sequestered calcium on prebiotics would then reach the colon where it was being released from the prebiotics matrix and absorbed in the colon [27]. Therefore, the ingestion of prebiotics would increase the absorption of calcium and reduce the risk of hypertension. The absorption of calcium has also been found to increase in the presence of acids in the intestines [28]. Prebiotics are indigestible and thus escape digestion and serve as substrate to the microflora population in the lower intestines. SCFA and $\mathrm{H}^{+}$have been found to exchange for $\mathrm{Ca}^{2+}$ in the distal colon regions [29]. This would then increase the concentration of $\mathrm{Ca}^{2+}$ which favour passive diffusion and consequently absorbed by the human colon [27].

\section{In-Vivo Evidence of Antihypertensive Effects}

Numerous studies have positively indicated that the consumption of plant-derived prebiotics could exert a protective effect against hypertension. Direct association of prebiotics and antihypertension has 
been established via various in-vivo trials (Table 1). However, hypertension is also highly associated with hypercholesterolemia and diabetes, where a lowering in cholesterol levels and improvement of glucose levels has been found to lower blood pressure. Prebiotics have been associated with the promotion of the overall well-being afflicted with blood glucose and blood lipid abnormalities (Table 2), while simultaneously exerting positive effect on blood pressure, thus reducing the risk factors of hypertension and coronary heart diseases.

Table 1. Antihypertensive effects of plant derived prebiotics.

\begin{tabular}{|c|c|c|c|c|c|}
\hline Intervention & $\begin{array}{l}\text { Experimental } \\
\text { design }\end{array}$ & Subjects & Dose & Effects & Ref \\
\hline $\begin{array}{l}\text { Soluble fiber } \\
\text { extracted from oat } \\
\text { bran }\end{array}$ & $\begin{array}{l}\text { Randomized, } \\
\text { double-blind, } \\
\text { placebo-controlled }\end{array}$ & $\begin{array}{l}\mathrm{n}=110 ; 30 \text { to } 65 \text { years; } \\
\text { not on hypertension } \\
\text { treatment; SBP of } \\
125-159 \mathrm{mmHg} \text { and } \\
\text { DBP of }<95 \mathrm{mmHg}\end{array}$ & $\begin{array}{l}8 \mathrm{~g} / \mathrm{d} \text { of fiber for } \\
12 \text { weeks }\end{array}$ & $\begin{array}{l}\text { A reduction in } \\
\text { SBP of } 2.0 \mathrm{mmHg} \\
\text { and DBP of } 1.0 \\
\mathrm{mmHg}\end{array}$ & [30] \\
\hline $\begin{array}{l}\text { Diet containing soy } \\
\text { protein isolate and } \\
\text { supplementation of } \\
\text { fiber extracted from } \\
\text { psyllium }\end{array}$ & $\begin{array}{l}\text { Randomized, } \\
\text { double-blind, } \\
\text { parallel }\end{array}$ & $\begin{array}{l}\mathrm{n}=36 \text {; nonsmoking } \\
\text { men or women }>20 \\
\text { years old; on } \\
\text { antihypertensive drug } \\
\text { therapy for }>6 \\
\text { months; SBP of } 130 \text { - } \\
160 \mathrm{mmHg}\end{array}$ & $\begin{array}{l}12 \mathrm{~g} \text { fiber/d for } 8 \\
\text { weeks }\end{array}$ & $\begin{array}{l}\text { A reduction in } \\
\text { SBP of } 5.9 \mathrm{mmHg}\end{array}$ & [31] \\
\hline $\begin{array}{l}\text { Dietary fiber in the } \\
\text { form of pill } \\
\text { supplementation }\end{array}$ & $\begin{array}{l}\text { Randomized, } \\
\text { double-blind, } \\
\text { parallel, placebo- } \\
\text { controlled }\end{array}$ & $\begin{array}{l}\mathrm{n}=63 ; 18-70 \text { yrs old; } \\
\text { hypertensive with a } \\
\text { minimum DBP of }> \\
90 \mathrm{mmHg}\end{array}$ & $\begin{array}{l}7 \mathrm{~g} / \mathrm{d} \text { of dietary } \\
\text { fiber for } 12 \\
\text { weeks }\end{array}$ & $\begin{array}{l}\text { A reduction in } \\
\text { DBP of } 5 \mathrm{mmHg}\end{array}$ & [32] \\
\hline $\begin{array}{l}\text { Beta-glucan from } \\
\text { whole oats cereals }\end{array}$ & $\begin{array}{l}\text { Randomized, } \\
\text { parallel, pilot trial }\end{array}$ & $\begin{array}{l}\mathrm{n}=18 ; 27-59 \text { years old; } \\
\text { healthy, untreated } \\
\text { hypertensives with } \\
\text { SBP of } 130-160 \\
\mathrm{mmHg} \text { and DBP of } \\
85-100 \mathrm{mmHg}\end{array}$ & $\begin{array}{l}5.52 \mathrm{~g} / \mathrm{d} \text { of beta- } \\
\text { glucan for } 6 \\
\text { weeks }\end{array}$ & $\begin{array}{l}\text { A reduction in } \\
\text { SBP of } 7.5 \mathrm{mmHg} \\
\text { and DBP of } 5.5 \\
\text { mmHg }\end{array}$ & [33] \\
\hline $\begin{array}{l}\text { Bread substituted } \\
\text { with lupin kernel } \\
\text { flour }\end{array}$ & $\begin{array}{l}\text { Randomized, } \\
\text { parallel }\end{array}$ & $\begin{array}{l}\mathrm{n}=74 ; 20-70 \text { years old; } \\
\text { overweight and obese } \\
\text { men and women with } \\
\text { BMI of } 25-35 \text {; } \\
\text { SBP }<150 \mathrm{mmHg} \text { and } \\
\mathrm{DBP}<95 \mathrm{mmHg}\end{array}$ & $\begin{array}{l}4 \times 40 \mathrm{~g} \text { of } \\
\mathrm{bread} / \mathrm{d} \text { for } 16 \\
\text { weeks; Bread } \\
\text { contained } 9.5 \% \\
\text { w/w of fiber }\end{array}$ & $\begin{array}{l}\text { A reduction in } \\
\text { SBP of } 3.0 \mathrm{mmHg}\end{array}$ & [34] \\
\hline
\end{tabular}

SBP: systolic blood pressure; DBP: diastolic blood pressure.

Table 2. Effects of dietary fiber on blood glucose and lipid profiles.

\begin{tabular}{|c|c|c|c|c|c|c|}
\hline Intervention & Fiber & $\begin{array}{l}\text { Dose; duration } \\
\text { of the study }\end{array}$ & $\begin{array}{l}\text { Experimental } \\
\text { design }\end{array}$ & Animals/Subjects & Effects & Ref \\
\hline \multirow[t]{2}{*}{$\begin{array}{l}\text { Blood } \\
\text { Glucose }\end{array}$} & $\begin{array}{l}\text { Alginate } \\
\text { fiber }\end{array}$ & $\begin{array}{l}5.0 \text {-g sodium } \\
\text { alginate } \\
\text { supplement } \\
\text { (algaeisolate, } \\
75 \% \text { soluble } \\
\text { fiber); for two } \\
\text { days }\end{array}$ & $\begin{array}{l}\text { Randomized, } \\
\text { placebo- } \\
\text { controlled }\end{array}$ & $\begin{array}{l}\text { Seven men with type } \\
2 \text { diabetes; mean age } \\
\text { of } 53 \text { years }\end{array}$ & $\begin{array}{l}\text { Significantly reduced } \\
\text { the postprandial rise in } \\
\text { blood glucose } \\
(P<0.05) \text { and in serum } \\
\text { insulin }(P<0.02) \text { by } \\
31 \% \text { and } 42 \% \text {, } \\
\text { respectively }\end{array}$ & {$[35]$} \\
\hline & Soy hulls & $\begin{array}{l}26 \mathrm{~g} \text { of soy } \\
\text { hulls which } \\
\text { incorporated } \\
\text { into } 7 \text { slices of } \\
\text { bread daily; for } \\
4 \text { weeks }\end{array}$ & $\begin{array}{l}\text { Randomized, } \\
\text { double-blind, } \\
\text { placebo- } \\
\text { controlled }\end{array}$ & $\begin{array}{l}\text { Ten subjects ( } 5 \text { male } \\
\text { and } 5 \text { female) with } \\
\text { type } 2 \text { diabetes; mean } \\
\text { age of } 65 \pm 5.9 \text { years }\end{array}$ & $\begin{array}{l}\text { Significantly } \\
\text { improved the glucose } \\
\text { score }(P<0.05) \text { and the } \\
\text { total area under the } \\
\text { glucose curve } \\
(P<0.05) \text { by } 6.7 \% \text { and } \\
7.1 \% \text {, respectively }\end{array}$ & {$[36]$} \\
\hline
\end{tabular}


Table 2. Cont.

\begin{tabular}{|c|c|c|c|c|c|c|}
\hline \multirow[t]{2}{*}{ Lipid Profile } & Pectin & $\begin{array}{l}75 \mathrm{~g} \text { citrus } \\
\text { pectin daily; for } \\
\text { four weeks }\end{array}$ & $\begin{array}{l}\text { Randomized, } \\
\text { placebo- } \\
\text { controlled }\end{array}$ & $\begin{array}{l}\text { Six male adult } \\
\text { hypercholesterolemic } \\
\text { minipigs }\end{array}$ & $\begin{array}{l}\text { 67.1\% decrease in } \\
\text { VLDL- cholesterol } \\
(P<0.05) ; 41.1 \% \\
\text { decrease in LDL- } \\
\text { cholesterol }(P<0.05) \text {; } \\
49.4 \% \text { decrease in } \\
\text { total serum } \\
\text { cholesterol }(P<0.05)\end{array}$ & [37] \\
\hline & $\begin{array}{l}\text { Fiber } \\
\text { (Plantago } \\
\text { ovata } \\
\text { husk) }\end{array}$ & $\begin{array}{l}10.5 \text { g Plantago } \\
\text { ovata husk } \\
\text { daily; for eight } \\
\text { weeks }\end{array}$ & $\begin{array}{l}\text { Randomized, } \\
\text { crossover, } \\
\text { placebo- } \\
\text { controlled, } \\
\text { single-blind }\end{array}$ & $\begin{array}{l}\text { Twenty-eight men } \\
\text { with myocardial } \\
\text { infarction or stable } \\
\text { angina }\end{array}$ & $\begin{array}{l}6.7 \% \text { decrease in } \\
\text { plasma } \\
\text { triacylglycerol } \\
(P<0.02), 6.7 \% \\
\text { increase in HDL- } \\
\text { cholesterol } \\
\text { concentrations } \\
(P<0.006) ; 10.6 \% \\
\text { decrease in the total } \\
\text { cholesterol/HDL } \\
\text { ratio }(P<0.002) ; \\
14.2 \% \text { decrease in } \\
\text { LDL/HDL ratio } \\
(P<0.003)\end{array}$ & [38] \\
\hline
\end{tabular}

\subsection{Hypercholesterolemia}

In a study evaluating the influence of prebiotics on cholesterol, Mortensen et al. [39] administered a purified diet with $10 \%$ of long-chained fructan into male mice for 16 weeks. The control was not fed any prebiotics. The study involved 40 male mice and the results showed that the supplementation of fructan significantly reduced blood cholesterol by $29.7 \%(P<0.001)$, LDL-cholesterol concentration by 25.9\% $(P<0.01)$, IDL-cholesterol level by 39.4\% $(P<0.001)$ and VLDL-cholesterol concentration by $37.3 \%(P<0.05)$ compared to the control group.

Davidson and Maki [40] conducted a randomized, double-blind, placebo-controlled and crossover design trial for 12 weeks involving 21 healthy volunteers to study the effect of prebiotic on lipid profiles. The authors found that the daily consumption of $18 \mathrm{~g} /$ day of inulin-supplemented foods significantly reduced plasma total cholesterol $(P<0.02)$ and LDL-cholesterol $(P<0.005)$ by $8.7 \%$ $( \pm 3.3)$ and $14.4 \%( \pm 4.3)$, respectively compared to the control. In another study, Rault-Nania et al. [41] found that male Wistar rats fed with a diet containing inulin and oligofructose for 4 weeks showed a significant $(P<0.05)$ decrease in hepatic triglycerides concentration as compared to those in the control group, whereby the blood pressure of those on inulin and oligofructose were in the range of $138.0 \pm 2.2$ and $136.9 \pm 2.0 \mathrm{~mm} \mathrm{Hg}$ respectively, while the control showed a blood pressure of $145.8 \pm 1.3 \mathrm{~mm} \mathrm{Hg}$.

Hypertriglyceridemia is often associated with a moderate hyperglycemia and insulinemia [42], and prebiotics have been found to reduce hepatic triacylglycerol. Daubioul et al. [43] administered $10 \mathrm{~g}$ of fructan to male mice for eight weeks. The study involved 16 male obese mice and the results showed that the fructan treatment significantly reduced $(P<0.05)$ hepatic triacylgylcerol by $48 \%$ compared to the control group. In another study, Busserolles et al. [44] found that male Wistar-Han rats fed with a diet containing oligofructose for four weeks showed a significant $(P<0.05)$ decline of $0.33 \%$ in hepatic triacylglycerol as compared to the control. These studies provided the experimental and clinical 
evidence that the supplementation of prebiotics such as inulin and oligofructose could be used as a mean to control hypertension.

\subsection{Diabetes}

Experimental evidence has also demonstrated that diabetes elevates the risk of hypertension [45]. Dietary intervention is one of the main therapies proposed to diabetics, thus prebiotics have gained increasing attention because of their beneficial effects on lowering blood glucose. Therefore, prebiotics could act as antihypertensive agents upon the exhibition of blood glucose lowering effects. In a study evaluating the improvement of glucose tolerance via the intake of prebiotics, Cani et al. [46] administered an oligofructose-supplemented diet $[10 \%(\mathrm{w} / \mathrm{w})]$ to male mice for 14 weeks. The study used 32 male mice and the results showed that mice in the group consuming diet supplemented with oligofructose had improved glucose tolerance as compared to those in the control group. Mice on the oligofructose-supplemented diet showed normal fasting plasma insulin levels and restored glucoseinduced insulin secretion while the control did not. In another study, Frias and Sgarbieri [47] found that male Wistar rats $(n=120)$ fed with diet containing $20 \%(\mathrm{w} / \mathrm{w})$ of guar gum for 60 days showed a significantly $(P<0.05)$ reduced serum glucose. Similarly, Kok et al. [48] studied the effects of oligofructose-enriched diet on glucose metabolism using rats as a model. The study involved 22 male Wistar rats that were fed a nonpurified diet and were randomly divided into two groups: those receiving nonpurified diet with 10\% oligofructose (treatment group), or without oligofructose (control group) for 30 days. Throughout the 30-day treatment, the treatment group showed a significantly $(P<0.05)$ reduced blood glucose by $26.0 \%$ as compared to those of the control group which only showed a reduction of $9.7 \%$, which was insignificant statistically. The finding indicated that diet supplemented with oligofructose was effective in reducing blood glucose and indirectly could alleviate the risks of hypertension.

Similarly, Suzuki and Hara [49] studied the effects of guar gum hydrolysate-enriched diet on glucose tolerance using rats as a model. The study used 31 male Sprague-Dawley rats that were fed a diet containing guar gum hydrolysate $(75 \mathrm{~g} / \mathrm{kg})$ for 30 days. The treatment contributed to a significant $(P<0.05)$ improvement of glucose intolerance as compared to the control. Giacco et al. [50] evaluated the effect of short-chain-fructooligosaccharides on glucose tolerance in 30 volunteers. The randomized, double-blind, placebo-controlled and crossover trial for two months showed that daily consumption of $10 \mathrm{~g} /$ day of short-chain-fructooligosaccharides contributed to a significant $(P<0.02)$ reduction of postprandial insulin response as compared to those in the placebo group which did not show any significant differences.

Various studies have highlighted the beneficial effects of prebiotics on physiological conditions such as lipid and glucose profiles that are directly associated with hypertension. Hence, there is a strong basis for continuous evaluation on prebiotics specifically aimed at utilizing longer and larger in-vivo trials. 


\section{Controversial Studies}

Epidemiological studies have found that hypertensive patients frequently have a high level of serum cholesterol. Blood pressure and cholesterol are closely related and many researches have demonstrated that the lowering of cholesterol contributes to antihypertension effects. Thus, an increase in both serum cholesterol and triglycerides had been reported to elevate blood pressure values [51]. According to Boyd et al. [52] and Ferrara et al. [51], blood pressure elevated with a higher prevalence of low HDL-cholesterol and high LDL-cholesterol levels while mildly increased serum cholesterol levels are able to influence hypertension. Although increasing uptake of prebiotics have been reported to reduce plasma lipid levels, controversies are raised where a number of studies have reported otherwise.

According to Luo et al. [53], blood lipids in twelve healthy volunteers were not affected by the consumption of nondigestible oligosaccharides (NDO) such as short-chain fructooligosaccharides (FOS). The consumption of FOS enriched cookies (20 g/day) in a double-blind randomized crossover design over 4 weeks showed that serum triacylglycerol, total- and HDL cholesterol, apoliprotein A-I and $\mathrm{B}$ and lipoprotein concentrations remained relatively constant and did not differ compared to the control. In another randomized, double-blind and diet-controlled study involving twelve healthy men, Van Dokkum et al. [54] showed that the cholesterol lowering effect of NDO was insignificant. The incorporation of inulin, FOS and galacto-oligosaccharides (GOS) in food products in quantities up to $15 \mathrm{~g} /$ day did not exhibit a reduction in blood lipid profiles. Although factors such as healthy subjects and low concentrations of initial serum cholesterol could affect the outcomes of these studies, the results showed that NDO may not possess antihypertensive effects.

In another study, Pedersen et al. [55] reported that the daily intake of $14 \mathrm{~g}$ of inulin added to a low fat spread in the diet of sixty-four healthy young females in a randomized double-blind crossover study involving two periods of four weeks did not affect the concentrations of triacylglycerols, HDL and LDL-cholesterol. There was insignificant difference in blood lipids between the placebo and treatment group. Ellegard et al. [56] also showed similar findings. In a double-blind crossover study, the consumption of $16-17 \mathrm{~g} / \mathrm{d}$ of inulin and FOS in a controlled diet by ten subjects with conventional ileostomy did not show significant effects on absorption and excretion of cholesterol. In another study by Williams [57], fifty-eight middle-aged hypercholesterolemic subjects consuming $10 \mathrm{~g} /$ day of inulin showed insignificant changes in total, LDL or HDL-cholesterol or apolipoproteins B and A over eight weeks.

Jenkins et al. [58] used a crossover design involving eight healthy subjects and showed that daily ingestion of 18-25 g/day of lactulose in dissolved water over two weeks not only did not reduce lipid concentrations but raised the fasting serum total- and LDL-cholesterol and apoliprotein B concentrations. The authors reported that the failure of lactulose to lower serum lipids may related to inadequate generation of propionate and predominant of acetate short chain fatty acids (SCFA) because six of the eight subjects showed higher serum acetate concentrations. In another animal study involving rats as a model also showed a significant rise in liver cholesterol concentrations after four weeks of dietary supplementation with lactulose [59]. Fermentable dietary fibers such as prebiotics escape digestion in small intestine and are fermented in the cecum and colon, producing SCFA mainly acetate, propionate and butyrate [60]. According to Beynen et al. [61], acetate is a precursor of cholesterol synthesis and it has been shown to enhance lipogenesis in rat hepatocytes. 
The concordance of hypertension and diabetes is increased in the population and hypertension is disproportionately higher in diabetics [62]. High blood glucose levels in hyperglycemia patients are more likely to elevate blood pressure [63]. Although prebiotics have been widely reported to improve blood glucose profiles, some studies have also suggested otherwise. Alles et al. [64] previously used a randomized, single-blind, placebo-controlled and crossover design involving twenty patients with type 2 diabetes. The authors reported that the supplementation of FOS $(15 \mathrm{~g} / \mathrm{d})$ for 20 days did not significantly affect blood glucose concentrations in patients with type 2 diabetes. Luo et al. [65] also showed similar findings in a trial involving ten type 2 diabetic volunteers. These subjects received $20 \mathrm{~g} / \mathrm{d}$ FOS for four weeks in a double-blind crossover design. The authors found that FOS did not modify plasma glucose and insulin concentrations or basal hepatic glucose production. The authors attributed the absence of glucose lowering effect of FOS to the relatively small doses used in the subjects. In a randomized, single-blind and crossover study involving eighteen mildly hyperlipidemic subjects, Keogh et al. [66] demonstrated that the administration of $\beta$-glucan enriched barley for two period of four weeks did not significantly change blood glucose levels. In another study, McIntosh et al. [67] evaluated the effect of blood glucose upon the consumption of dietary fiber in a crossover trial involving twenty-one mildly hypercholesterolemic subjects. The authors found that the daily intake of 21-38 $\mathrm{g}$ of barley foods containing $\beta$-glucan and wheat containing cellulose and hemicelluloses fiber for four weeks did not alter the concentrations of blood glucose.

Future studies aimed at investigating the effects of prebiotics on serum cholesterol or blood glucose concentration should consider the choice of subjects and the length of the supplementation period. Past studies investigating on the effects of NDO such as inulin and FOS in humans on hypertension remains relatively controversial. However, considering the vast experimental evidence on their positive roles, the potential of prebiotics as an antihypertensive agents warrant further investigations.

\section{Conclusions}

Results from recent studies support the antihypertensive potential of plant-based prebiotics, and shown that they could exert such a beneficial effect via various mechanisms. Although controversial findings are raised, positive outcomes from both in-vitro experiments and in-vivo trials have exhibited the need for further evaluation of the antihypertensive properties of plant-based prebiotics.

\section{Acknowledgments}

This paper was prepared as supported by the Research University Grant (1001/PTEKIND/811089) and USM Fellowships provided by Universiti Sains Malaysia, and the eScienceFund Grant (305/PTEKIND/613218) provided by the Malaysian Ministry of Science, Technology and Innovation.

\section{References and Notes}

1. Wang, T.J.; Vasan, R.S. Epidemiology of Uncontrolled Hypertension in the United States. Circulation 2005, 112, 1651-1662. 
2. Hobbs, F.D.R. Primary Prevention of Cardiovascular Disease: Managing Hypertension and Hyperlipidaemia. Heart 2004, 90, iv22-iv25.

3. Brown, N.J.; Vaughan, D.E. Angiotensin-Converting Enzyme Inhibitors. Circulation 1998, 97, 1411-1420.

4. Kim, M.; Shin, H.K. The Water-Soluble Extract of Chicory Influences Serum and Liver Lipid Concentrations, Cecal Short-Chain Fatty Acid Concentrations and Fecal Lipid Excretion in Rats. J. Nutr. 1998, 128, 1731-1736.

5. Chen, W.J.L.; Anderson, J.W. Soluble and Insoluble Plant Fiber in Selected Cereals and Vegetables. Am. J. Clin. Nutr. 1981, 34, 1077-1082.

6. Ferrier, K.E.; Muhlmann, M.H.; Baguet, J.-P.; Cameron, J.D.; Jennings, G.L.; Dart, A.M.; Kingwell, B.A. Intensive Cholesterol Reduction Lowers Blood Pressure and Large Artery Stiffness in Isolated Systolic Hypertension. J. Am. Coll. Cardiol. 2002, 39, 1020-1025.

7. Levrat-Verny, M.A.; Behr, S.; Mustad, V.; Rémésy, C.; Demigné, C. Low Levels of Viscous Hydrocolloids Lower Plasma Cholesterol in Rats Primarily by Impairing Cholesterol Absorption. J. Nutr. 2000, 130, 243-248.

8. Gallaher, D.D.; Gallaher, C.M.; Mahrt, G.J.; Carr, T.P.; Hollingshead, C.H.; Hesslink, R., Jr.; Wise, J. A Glucomannan and Chitosan Fiber Supplement Decreases Plasma Cholesterol and Increases Cholesterol Excretion in Overweight Normocholesterolemic Humans. J. Am. Coll. Nutr. 2002, 21, 428-433.

9. Aller, R.; de Luis, A.D.; Izaola, O.; La Calle, F.; del Olmo, L.; Fernandez, L.; Arranz, T.; Hernandez, J.M.G. Effect of Soluble Fiber Intake in Lipid and Glucose Levels in Healthy Subjects: A Randomized Clinical Trial. Diabetes Res. Clin. Prac. 2004, 65, 7-11.

10. Lairon, D.; Arnault, N.; Bertrais, S.; Planells, R.; Clero, E.; Hercberg, S.; Boutron-Ruault, M.-C. Dietary Fiber Intake and Risk Factors for Cardiovascular Disease in French Adults. Am. J. Clin. Nutr. 2005, 82, 1185-1194.

11. Rahmouni, K.; Correia, M.L.G.; Haynes, W.G.; Mark, A.L. Obesity-Associated Hypertension: New Insights into Mechanisms. Hypertens 2005, 45, 9-14.

12. Cani, P.D.; Neyrinck, A.M.; Maton, N.; Delzenne, N.M. Oligofructose Promotes Satiety in Rats Fed a High-Fat Diet: Involvement of Glucagon-Like Peptide-1. Obesity Res. 2005, 13, 1000-1007.

13. Delzenne, N.M.; Cani, P.D.; Neyrinck, A.M. Modulation of Glucagon-Like Peptide 1 and Energy Metabolism by Inulin and Oligofructose: Experimental Data. J. Nutr. 2007, 137, 2547S-2551S.

14. Piche, T.; des Varannes, S.B.; Sacher-Huvelin, S.; Holst, J.J.; Cuber, J.C.; Galmiche, J.P. Colonic Fermentation Influences Lower Esophageal Sprincter. Gastroenterology 2003, 124, 894-902.

15. Cani, P.D.; Joly, E.; Horsmans, Y.; Delzenne, N.M. Oligofructose Promotes Satiety in Healthy Human: A Pilot Study. Eur. J. Clin. Nutr. 2006, 60, 567-572.

16. Ange, B.A.; Appel, L.J. The Effect of Macronutrient and Dietary Pattern on Blood Pressure. In Hypertension: Principle and Practice; Battegay, E., Lip, G.Y.H., Bakris, G.L., Eds.; Informa Health Care: New York, NY, USA, 2005; pp. 169-181.

17. Saad, M.F.; Rewer, M.; Selby, J.; Howard, G.; Jinagouda, S.; Fahmi, S.; Zaccaro, D.; Bergman, R.N.; Savage, P.J.; Haffner, S.M. Insulin Resistance and Hypertension: The Insulin Resistance Atherosclerosis Study. Hypertens 2004, 43, 1324-1331. 
18. Robertson, M.D.; Currie, J.M.; Morgan, L.M.; Jewell, D.P.; Frayn, K.N. Prior Short-Term Consumption of Resistant Starch Enhances Postprandial Insulin Sensitivity in Healthy Subjects. Diabetol 2003, 46, 659-665.

19. Schulze, M.B.; Schulz, M.; heidemann, C.; Scienkiewitz, A.; Hoffmann, K.; Boeing, H. Fiber and Magnesium Intake and Incidence of Type 2 Diabetes: A Prospective Study and Meta-analysis. Arch. Intern. Med. 2007, 167, 956-965.

20. Weickert, M.O.; Mohlig, M.; Schofl, C.; Arafat, A.M.; Otto, B.; Viehoff, H.; Koebnick, C.; Kohl, A.; Spranger, J.; Pfeiffer, A.F. Cereal Fiber Improves Whole-Body Insulin Sensitivity in Overweight and Obese Women. Diabetes Care 2006, 29, 775-780.

21. Ludwig, D.S. The Glycemic Index: Physiological Mechanisms Relating to Obesity, Diabetes, and Cardiovascular Disease. JAMA 2002, 287, 2414-2423.

22. Streppel, M.T.; Arends, L.R.; van't Veer, P.; Grobbee, D.E.; Geleijnse, J.M. Dietary Fiber and Blood Pressure: A Meta-Analysis of Randomized Placebo-Controlled Trials. Arch. Intern. Med. 2005, 165, 150-156.

23. Allender, P.S.; Cutler, J.A.; Follmann, D.; Cappucio, F.P.; Pryer, J.; Elliott, P. Dietary Calcium and Blood Pressure: A Meta-Analysis of Randomized Clinical Trials. Ann. Intern. Med. 1996, 124, 825-831.

24. Zemel, M.B. Calcium Modulation of Hypertension and Obesity: Mechanism and Implication. $J$. Am. Coll. Nutr. 2001, 20, 428S-435S.

25. Griessen, M.; Ammann, P.; Selz, L.; Bartholdi, P.; Arnaud, M.J.; Bonjour, J.-P.; Blanchard, J. Comparison of the Effect of Medium-Chain and Long-Chain Triacylglycerols on Calcium Absorption in Healthy Subjects. Am. J. Clin. Nutr. 1999, 69, 1237-1242.

26. Abram, S.A.; Griffin, I.J.; Hawthorne, K.M.; Liang, L.; Gunn, S.K.; Darlington, G.; Eliis, K.J. A Combination of Prebiotics Short- and Long-Chain Inulin Type Frutans Enhances Calcium Absorption and Bone Mineralization in Young Adolescents. Am. J. Clin. Nutr. 2005, 82, 471-476.

27. Roberfroid, M.B. Prebiotics and Probiotics: Are They Functional Foods? Am. J. Clin. Nutr. 2000, 71, 1682S-1687S.

28. Scholz-Ahrens, K.E.; Schaafsma, G.; van den Heuvel, E.G.H.M.; Schrezenmeir, J. Effects of Prebiotics on Mineral Metabolism. Am. J. Clin. Nutr. 2001, 73, 459S-464S.

29. Trinidad, T.P.; Wolever, T.M.; Thompson, L.U. Effect of Acetate and Propionate on Calcium Absorption from the Rectum and Distal Colon of Humans. Am. J. Clin. Nutr. 1996, 63, 574-578.

30. He, J.; Streiffer, R.H.; Whelton, P.K. Effect of Dietary Fiber Supplementation on Blood Pressure: A Randomized, Double-Blind Placebo-Controlled Trial. J. Hypertens. 2004, 22, 73-80.

31. Burke, V.; Hodgson, J.M.; Beilin, L.J.; Giangiulioi, N.; Rogers, P.; Puddey, I.B. Dietary Protein and Soluble Fiber Reduce Ambulatory Blood Pressure in Treated Hypertensives. Hypertension 2001, 38, 821-826.

32. Eliasson, K.; Ryttig, K.R.; Hylander, B.; Rossner, S. A Dietary Fibre Supplement in the Treatment of Mild Hypertension: A Randomized, Double Blind, Placebo-Controlled Trail. J. Hypertens. 1992, 10, 195-199.

33. Keenan, J.M.; Pins, J.J.; Frazel, C.; Moran, A.; Turnquist, L. Oat Ingestion Reduces Systolic and Diastolic Blood Pressure in Patients with Mild or Borderline Hypertension: A Pilot Trial. J. Fam. Pract. 2002, 51, 369. 
34. Lee, Y.P.; Mori, T.A.; Puddey, I.B.; Sipsas, S.; Ackland, T.R.; Beilin, L.J.; Hodgson, J.M. Effects of Lupin Kernel Flour-Enriched Bread on Blood Pressure: A Controlled Intervention Study. Am. J. Clin. Nutr. 2009, 89, 766-772.

35. Torsdottir, I.; Alpsten, M.; Holm, G.; Sanberg, A.-S.; Tö-Lli, J. A Small Dose of Soluble Alginate-Fiber Affects Postprandial Glycemia and Gastric Emptying in Humans with Diabetes. $J$. Nutr. 1991, 121, 795-799.

36. Mahalko, J.R.; Sandstead, H.H.; Johnson, L.A.K.; Inman, L.F.; Milne, D.B.; Warner, R.C.; Haunz, E.A. Effect of Consuming Fiber from Corn Bran, Soy Hulls, or Apple Powder on Glucose Tolerance and Plasma Lipids in Type II Diabetes. Am. J. Clin. Nutr. 1984, 39, 25-34.

37. Ahrens, F.; Hagemeister, H.; Pfeuffer, M.; Barth, C.A. Effects of Oral and Intracecal Pectin Administration on Blood Lipids in Minipigs. J. Nutr. 1986, 116, 70-76.

38. Solà, R.; Godàs, G.; Ribalta, J.; Vallvé, J.C.; Girona, J.; Anguera, A.; Ostos, M.; Recalde, D.; Salazar, J.; Caslake, M.; Martín-Luján, F.; Salas-Salvadó, J.; Masana, L. Effects of Soluble Fiber (Plantago ovata Husk) on Plasma Lipids, Lipoproteins, and Apolipoproteins in Men with Ischemic Heart Disease. Am. J. Clin. Nutr. 2007, 85, 1157-1163.

39. Mortensen, A.; Poulsen, M.; Frandsen, H. Effect of a Long-Chained Fructan Raftiline HP on Blood Lipids and Spontaneous Atherosclerosis in Low Density Receptor Knockout Mice. Nutr. Res. 2002, 22, 473-480.

40. Davidson, M.H.; Maki, K.C. Effects of Dietary Inulin on Serum Lipids. J. Nutr. 1999, 129, 1474-1477.

41. Rault-Nania, M.-H.; Demougeot, C.; Gueux, E.; Berthelot, A.; Dzimira, S.; Rayssiguier, Y.; Rock, E.; Mazur, A. Inulin Supplementation Prevents High Fructose Diet-Induced Hypertension in Rats. Clin. Nutr. 2008, 27, 276-282.

42. Kok, N.; Roberfroid, M.; Delzenne, N. Dietary Oligofructose Modifies the Impact of Fructose on Hepatic Triacylglycerol Metabolism. Metabolism 1996, 45, 1547-1550.

43. Daubioul, C.; Rousseau, N.; Demeura, R.; Gallez, B.; Taper, H.; Declerck, B.; Delzenne, N. Dietary Fructans, but Not Cellulose, Decrease Triglycerides Accumulation in the Liver of Obese Zucker Fa/Fa Rats. J. Nutr. 2002, 132, 967-973.

44. Busserolles, J.; Gueux, E.; Rock, E.; Demigne, C.; Mazur, A.; Rayssiguier, Y. Oligofructose Protects Against Hypertriglyceridemic and Pro-Oxidative Effects of a High Fructose Diet in Rats. J. Nutr. 2003, 133, 1903-1908.

45. Slavin, J.L. Position of the American Dietetic Association: Health Implications of Dietary Fiber. J. Am. Diet. Assoc. 2008, 108, 1716-1731.

46. Cani, P.D.; Neyrinck, A.M.; Fava, F.; Knauf, C.; Burcelin, R.G.; Tuohy, K.M.; Gibson, G.R.; Delzenne, N.M. Selective Increases of Bifidobacteria in Gut Microflora Improve High-Fat-DietInduced Diabetes in Mice Through a Mechanism Associated with Endotoxaemia. Diabetologia 2007, 50, 2374-2383.

47. Frias, A.C.D.; Sgarbieri, V.C. Guar Gum Effects on Food Intake, Blood Serum Lipids and Glucose Levels of Wistar Rats. Plant Food Hum. Nutr. 1998, 53, 15-28.

48. Kok, N.N.; Morgan, L.M.; Williams, C.M.; Roberfroid, M.B.; Thissen, J.P.; Delzenne, N.M. Insulin, Glucagon-Like Peptide 1, Glucose-Dependent Insulinotropic Polypeptide and Insulin- 
Like Growth Factor I as Putative Mediators of the Hypolipidemic Effect of Oligofructose in Rats. J. Nutr. 1998, 128, 1099-1103.

49. Suzuki, T.; Hara, H. Ingestion of Guar Gum Hydrolysate, a Soluble and Fermentable Nondigestible Saccaride, Improves Glucose Intolerance and Prevents Hypertriglyceridemia in Rats Fed Fructose. J. Nutr. 2004, 134, 1942-1947.

50. Giaccoa, R.; Clementea, G.; Luongoa, D.; Lasorellaa, G.; Fiumea, I.; Brounsb, F.; Bornetc, F.; Pattid, L.; Ciprianod, P.; Rivellesed, A.A.; Riccardid, G. Effects of Short-Chain FructoOligosaccharides on Glucose and Lipid Metabolism in Mild Hypercholesterolaemic Individuals. Clin. Nutr. 2003, 23, 331-340.

51. Ferrara, L.A.; Guida, L.; Iannuzzi, R.; Celentano, A.; Lionello, F. Serum Cholesterol Affects Blood Pressure Regulation. J. Hum. Hypertens 2002, 16, 337-343.

52. Boyd, G.S.; Koenigsberg, J.; Falkner, B.; Gidding, S.; Hassink, S. Effects of Obesity and High Blood Pressure on Plasma Lipid Levels in Children and Adolescents. Pediatrics 2005, 116, 442-446.

53. Luo, J.; Rizkalla, S.W.; Alamowitch, C.; Boussairi, B.; Blayo, A.; Barry, J.L.; Laffitte, A.; Guyon, F.; Bornet, F.R.J.; Slama, G. Chronic Consumption of Short-Chain Fructooligosaccharides by Healthy Subjects Decreased Basal Hepatic Glucose Production but Had No Effect on InsulinStimulated Glucose Metabolism. Am. J. Clin. Nutr. 1996, 63, 939-945.

54. van Dokum, W.; Wezendonk, B.; Srikumar, T.; van den Heuvel, E.G.H.M. Effect of Nondigestible Oligosachharides on Large-Bowel Functions, Blood Lipid Concentrations and Glucose Absorption in Young Healthy Male Subjects. Eur. J. Clin. Nutr. 1999, 53, 1-7.

55. Pedersen, A.; Sandström, B.; van Amelsvoort, J.M.M. The Effect of Ingestion of Inulin on Blood Lipids and Gastrointestinal Symptoms in Healthy Females. Br. J. Nutr. 1997, 78, 215-222.

56. Ellegard, L.; Andersson, H.; Bosaeus, I. Inulin and Oligofructose Do Not Influence the Absorption of Cholesterol, or the Excretion of Cholesterol, $\mathrm{Ca}, \mathrm{Mg}, \mathrm{Zn}, \mathrm{Fe}$, or Bile Acids but Increases Energy Excretion in Ileostomy Subjects. Eur. J. Clin. Nutr. 1997, 51, 1-5.

57. Williams, C.M. Effects of Inulin on Lipid Parameters in Humans. J. Nutr. 1999, 129, 1471S-1473S.

58. Jenkins, D.J.A.; Wolever, T.M.S.; Jenkins, A.; Brighenti, F.; Vuksan, V.; Rao, A.V.; Cunnane, S.C.; Ocana, A.; Corey, P.; Vezina, C.; Connelly, P.; Buckley, G.; Patten, R. Specific Types of Colonic Fermentation May Raise Low-Density-Lipoprotein-Cholesterol Concentrations. Am. J. Clin. Nutr. 1991, 54, 141-147.

59. Beynen, A.C. Dietary Lactulose and Cholesterol Metabolism in Rats. Nutr. Rep. Int. 1988, 37, 401-405.

60. Hosoya, N.; Dhorranintra, B.; Hidaka, H. Utilization of U14-C Fructo-Oligasaccharides in Man as Energy Resources. J. Clin. Biochem. Nutr. 1998, 5, 67-74.

61. Beynen, A.C.; Buechler, K.F.; van der Molen, A.J.; Geenlen, M.J.H. The Effect of Lactate and Acetate on Fatty Acid and Cholesterol Biosynthesis by Isolated Rat Hepatocytes. Int. J. Biochem. 1982, 14, 165-169.

62. Sowers, J.R.; Haffner, S. Treatment of Cardiovascular and Renal Risk Factors in the Diabetic Hypertensive. Hypertens 2002, 40, 781-788. 
63. Chobanian, A.V.; Bakris, G.L.; Black, H.R.; Cushman, W.C.; Green, L.A.; Izzo, J.L.; Jones, D.W.; Materson, B.J.; Oparil, S.; Wright, J.T.; Roccella, E.J. Seventh Report of the Joint National Committee on Prevention, Detection, Evaluation, and Treatment of High Blood Pressure. Hypertens 2003, 42, 1206-1252.

64. Alles, M.S.; de Ross, N.M.; Bakx, J.C.; van de Lisdonk, E.; Zock, P.L.; Hautvast, J.G.A.J. Consumption of Fructooligosaccharides Does Not Favorably Affect Blood Glucose and Serum Lipid Concentrations in Patients with Type 2 Diabetes. Am. J. Clin. Nutr. 1999, 69, 64-69.

65. Luo, J.; Yperselle, M.V.; Rizkalla, S.W.; Rossi, F.; Bornet, F.R.J.; Slama, G. Chronic Consumption of Short-Chain Fructooligosaccharides Does Not Affect Basal Hepatic Glucose Production or Insulin Resistance in Type 2 Diabetics. J. Nutr. 2000, 130, 1572-1577.

66. Keogh, G.F.; Cooper, G.J.S.; Mulvey, T.B.; McArdle, B.H.; Coles, G.D.; Monro, J.A.; Poppitt, S.D. Randomized Controlled Crossover Study of the Effect of a Highly $\beta$-Glucan-Enriched Barley on Cardiovascular Disease Risk Factors in Mildly Hypercholesterolemic Men. Am. J. Clin. Nutr. 2003, 78, 711-718.

67. McIntosh, G.H.; Whyte, J.; McArthur, R.; Nestel, P.J. Barley and Wheat Foods: Influence on Plasma Cholesterol Concentrations in Hypercholesterolemic Men. Am. J. Clin. Nutr. 1991, 53, 1205-1209.

(C) 2009 by the authors; licensee Molecular Diversity Preservation International, Basel, Switzerland. This article is an open-access article distributed under the terms and conditions of the Creative Commons Attribution license (http://creativecommons.org/licenses/by/3.0/). 